Мішук I. П., igmislog@ukr.net, ORCID ID: 0000-0001-5661-0164, Researcher ID: F-4185-2019,

д.е.н., проф., завідувач кафедри підприємництва, торгівлі та логістики, Львівський торговельноекономічний університет, м. Львів

\title{
АКТУАЛЬНІ ПРОБЛЕМИ ЗАБЕЗПЕЧЕННЯ КОНКУРЕНТОСПРОМОЖНОСТІ ПРОДУКЦЇ̈ АПК УКРАЇНИ
}

\begin{abstract}
Анотація. В статті розглянуто актуальні проблеми розвитку АПК України у контексті забезпечення належного рівня конкурентоспроможності продукиії сільськогосподарських товаровиробників. Цілями статті $\epsilon$ дослідження сутності поняття “конкурентоспроможність”, систематизація основних складових ї̈ формування, визначення найбільш актуальних проблем забезпечення конкурентоспроможності агропродовольчої продукиії українських сільгоспвиробників в умовах сучасної економіки. Проведений аналіз сутнісного змісту конкурентоспроможності засвідчив багатоаспектність та багатовимірність даного поняття, яке визначається через рівень спроможності продукиії бути реалізованою на товарному ринку завдяки відповідності ї̈ властивостей як споживної вартості та визнанню споживачем ії переваги над товарами-аналогами, наявними на конкретних товарних ринках у певний період часу і призначених для реалізації певній групі споживачів. Обтрунтовано вимогу щзодо визначення конкурентоспроможності агропродовольчої продукиії виробника шляхом першочергового зосередження на питаннях очінювання корисності товару для споживачів кожної конкретної циільової групи, щчо діє у відповідному секторі ринку, визначення для даної продукції ијіни споживання, а також встановлення ринкової спроможності пропозииї - можливостей доведення на ринок товару з найвищзим рівнем відповідності вимогам споживачів. Аналіз спеціальної літератури, статистичної інформації та емпіричних даних дозволив визначити основні проблеми забезпечення конкурентоспроможності продукції підприємств АПК України на зовнішніх і внутрішніх продовольчих ринках. Наголошено на необхідності використання в господарській діяльності суб'єктів АПК Украӥни практики оцінювання фактичної конкурентоспроможності власної аграрної продукиії та прогнозного ї̈ розвитку за умови реалізації комплексу заходів із забезпечення ї̈ зростання. Подальші дослідження мають спрямовуватися на розробку системи заходів із цільового забезпечення підвищення конкурентоспроможності агропродовольчої продукції підприємств АПК України.
\end{abstract}

Ключові слова: конкурентоспроможність, агропродовольча продукція, аграрний сектор, зовнішні товарні ринки, внутрішній ринок продовольства, оцінювання конкурентоспроможності продукції.

Mishchuk I. P., igmislog@ukr.net, ORCID:0000-0001-5661-0164, Researcher ID: F-4185-2019,

Doctor of Economics, Professor, Head of the Department of Entrepreneurship, Trade and Logistics, Lviv University of Trade and Economics, Lviv

\section{CURRENT PROBLEMS OF ENSURING THE COMPETITIVENESS OF AGRICULTURAL PRODUCTS OF UKRAINE}

\begin{abstract}
The article considers the current problems of development of the agricultural-industrial complex of Ukraine in the context of ensuring the appropriate level of competitiveness of agricultural product producers. The aim of the article is to study the essence of the concept of "competitiveness", systematization of the main components of its formation, identification of the most actual problems of ensuring the competitiveness of agricultural-food products of Ukrainian agricultural producers in the modern economy conditions. The analysis of the essential content of competitiveness showed the multifaceted and multidimensional nature of this concept, which is determined by the level of ability of products to be sold in the commodity market due to its properties as consumer value and consumer recognition of its superiority over similar products available in specific commodity markets at certain time and intended for sale to a certain group of consumers. The requirement to determine the competitiveness of agricultural-food products by focusing on assessing the usefulness of goods for consumers of each target group operating in the relevant market sector, determining the consumer price for this product, as well as determining the market capacity of supply - opportunities to bring goods to market with the highest level of compliance with consumer requirements. The analysis of special literature, statistical information and empirical data allowed to identify the main problems of ensuring the competitiveness of products of agricultural enterprises of Ukraine in foreign and domestic food markets. Emphasis is placed on the need to
\end{abstract}


use in the economic activities of the agricultural-industrial complex of Ukraine the practice of assessing the actual competitiveness of its own agricultural products and its forecast development, subject to the implementation of a set of measures to ensure its growth. Further research should be aimed at developing a system of measures to ensure the competitiveness of agricultural-food products of agricultural enterprises of Ukraine.

Key words: competitiveness, agricultural-food products, agricultural sector, foreign commodity markets, domestic food market, assessment of product competitiveness.

\section{JEL Classification: F14, O13 \\ DOI: https://doi.org/10.36477/2522-1205-2021-64-01}

Постановка проблеми. Одним із найважливіших секторів економіки України вважається агропромисловий комплекс, розвиток якого відбувається завдяки сприятливим для розвитку сільського господарства природним умовам та наявності значного потенціалу споживчого ринку продуктів харчування. Суб'єкти господарювання вітчизняного АПК традиційно забезпечують формування основної частини продовольчих ресурсів, які в ході реалізації на споживчому ринку України виступають як товарне забезпечення більш як 70\% роздрібного товарообороту продовольчих товарів. Разом $з$ тим, приєднання України до європейської та світової економічної системи, лібералізація торгівлі, що відображається в динамічному зростанні обсягів надходження на внутрішній ринок найрізноманітніших імпортних харчових продуктів, служить чинником загострення конкуренції на ньому. Ще більш жорсткими для вітчизняної агропродовольчої продукції $є$ умови та вимоги іiі реалізації на зовнішніх ринках, де Україна виступає одним із активних експортерів зернових продуктів (пшениця, ячмінь, кукурудза), жирів та олії, олійних культур (ріпак, соя), а також меду, на фоні відносно незначних обсягів постачання більшості продуктів тваринництва та частини продукції рослинництва (овочі, фрукти, плоди та ягоди, баштанні культури, для вирощування яких вітчизняні аграрії мають сприятливі умови) та їх переробки. Все це об'єктивно вимагає від вітчизняних виробників агропродовольчої продукції нарощування зусиль із підвищення конкурентоспроможності агропродовольчої продукції.

Аналіз останніх досліджень і публікацій. Питання сутності конкуренції та конкурентоспроможності на рівні фундаментальних теоретичних засад висвітлені в працях I. Ансоффа, Дж. Кейнса, М. Портера, Д. Рікардо, П. Самуельсона, Б. Бермана, С. Брю і К. Макконелла, Г. Азоєва, Р. Фатхутдінова та ін. Проблеми забезпечення конкурентоспроможності агропродовольчої продукції в контексті розвитку аграрного сектора України, зовнішньої торгівлі вітчизняною сільськогосподарською продукцією в тій чи іншій мірі розглядалися в публікаціях вітчизняних учених-економістів В. Г. Андрійчука, О. Л. Гальцової, С. М. Кваші та Н. С. Голомші, В. Я. Месель-Веселяка, П. Т. Саблука, О. М. Шпичака та ін. Протягом останніх років результати своїх досліджень на пов'язану з цим тематику опублікували О. В. Кругляк [1], О. В. Захарчук [2],
Г. Є. Мазнєв [3], М. І. Пугачов [4] та ін. Проте економічна ситуація як в Україні, так і в світі загалом зазнала радикальних змін протягом 2020-2021 pp., що знайшло своє відображення в терміні “постковідна економіка", а головне - в зміні умов провадження будь-якого, в тому числі аграрного, бізнесу. Відповідно, виникає завдання щодо з'ясування змісту та характеру цього впливу на забезпечення конкурентоспроможності агропродовольчої продукції підприємств України.

Постановка завдання. Мета дослідження - дослідити сутність поняття “конкурентоспроможність”, систематизувати основні складові іiі формування, визначити найбільш актуальні проблеми забезпечення конкурентоспроможності агропродовольчої продукції українських сільгоспвиробників в умовах сучасної економіки.

Виклад основного матеріалу дослідження. Поглиблення інтеграції економіки України в європейське i світове економічне співтовариство об'єктивно зумовлює потребу в зміцненні конкурентних позицій вітчизняних товаровиробників як на зовнішніх, так і на внутрішніх товарних ринках, у тому числі на ринках аграрної продукції. При цьому економісти наголошують, що одним із основних чинників реалізації такого завдання $\epsilon$ підвищення ефективності виробничо-господарської діяльності підприємств АПК України та їх конкурентоспроможності завдяки забезпеченню належного рівня конкурентоспроможності їх продукції. У зв'язку з цим виникає потреба в уточненні сутності та змісту даного поняття, що вирізняється наявністю різних підходів, різних вимірів, різних базисів визначення конкурентоспроможності як відносної категорії, що встановлюється шляхом порівняння властивостей та параметрів продукції одного суб'єкта господарювання 3 характеристиками чи перевагами аналогічної продукції іншого підприємства - конкурента. Узагальнюючи наявні в спеціальній літературі підходи, К. Желуденко вказує на використання 3 цією метою варіантів співставлення продукції підприємства за властивостями та характеристиками продукції, за наявністю ринкових переваг та ступенем задоволення попиту споживачів, за прибутковістю виробника [5, с. 67]. У першому 3 варіантів конкурентоспроможність продукції трактується як “...комплекс іiї вартісних і якісних характеристик, що визначають успіх продукції на ринку і створюють іiі перевагу над товарами-аналогами" [6, с. 9]; в другому - як 


\section{Herald of Lviv University of Trade and Economics. Economic Sciences. № 64, 2021}

властивість продукції у визначений момент (коли продукція як товар пропонується на ринку) “...відповідати ...потребам споживачів за технічними, економічними та екологічними характеристиками" [7, с. 35], натомість для прихильників третього $з$ перерахованих підходів ключовою умовою $\epsilon$ здатність забезпечувати високий рівень доходів виробнику - завдяки відповідності якісних та вартісних характеристик продукції вимогам конкурентного ринку та спроможності повністю задовольняти потреби споживача [8, с. 89].

Поряд 3 цим, низка авторів, пропонуючи власні трактування конкурентоспроможності (для прикладу - наведені у статті I. Бурачек та О. Біленчук), фактично підміняе поняття конкурентоспроможності продукції визначенням близького до нього терміна "конкурентоспроможність підприємства" [9, с. 289]. У зв'язку з цим варто наголосити на тісному зв'язку конкурентоспроможності з оцінкою насамперед продукиії як споживної цінності, що визначається наявністю саме у продукту праці даного товаровиробника певних властивостей (відображених у вигляді технічних, естетичних, експлуатаційних, сервісних чи інших параметрів у тій мірі, що відповідає очікуванням споживача) та отримує визнання фактом придбання даної продукції (товару) завдяки визнанню споживачем іiі переваги над товарами-аналогами інших товаровиробників-конкурентів.

Більше того, під конкурентоспроможністю слід розуміти таку властивість продукції, яка відображає можливості іiі успішного продажу: а) певній групі споживачів; б) на визначеному ринку і в) у певний період часу. Останнє означає тісну “прив'язку” конкурентоспроможності продукції до сегментації споживачів на конкретних товарних ринках, до локалізації збуту та до його часової детермінації, що забезпечуються здійсненням підприємством-виробником заходів маркетингового та логістичного характеру і передбачають досягнення відповідності щодо таких вимог реалізації, як строки постачання, схеми і технології доставки, політика лояльності до споживачів і цінові знижки, реклама, сервіс, ціна тощо.

Важливим у цьому твердженні $\epsilon$ також необов'язковість врахування повного набору характеристик продукції (що забезпечують поняття якості продукції) для визначення конкурентоспроможності продукції, а можливість забезпечення даної властивості лише на основі тих особливостей продукції, які $є$ пріоритетними для цільової групи споживачів (тобто інші характеристики і властивості продукції до уваги не беруться) на конкретному внутрішньому, зовнішньому чи локальному ринку. Дані твердження стосуються i такого об'єкта дослідження, як агропродовольчий ринок, у межах якого можна організаційно виділити такі сектори, як ринок сільськогосподарської продукції (відбувається збут агропродукції, яка споживається у свіжому вигляді), ринок сільськогосподарської сировини (реалізовується продукція, що скеровується на промислову переробку) і ринок продовольства (де задовольняються потреби покупців у продовольчих товарах, отриманих після переробки сільськогосподарської сировини).

Виходячи з вищезазначеного, визначення конкурентоспроможності агропродовольчої продукції підприємства-виробника має зосереджуватися на питаннях оцінювання корисності товару для споживачів кожної конкретної цільової групи, що діє в зазначених секторах, визначенні для даної продукції т.зв. ціни споживання, а також встановленні ринкової спроможності пропозиції (під якою потрібно розуміти наявність можли-востей доведення на ринок товару 3 найбільш високим рівнем відповідності вимогам споживачів).

Як зазначають В. Серединська та О. Загородна, саме оцінка споживачами рівня конкурентоспроможності певної продукції має бути основним орієнтиром у діяльності товаровиробника на ринку, оскільки “...дозволяє: - оцінити рівень якості продукції на підприємстві, встановити фактори формування та виявити напрями поліпшення; - правильно визначити свою позицію на ринку і вносити зміни у виробничу програму на засадах маркетингу, зміцнити фінансовий стан; - спрогнозувати очікувану конкурентоспроможність нової продукції до моменту виведення іiі на ринок та уникнути можливої «невдачі»; - виробити варіанти управлінських рішень, які спрямовані на оптимізацію процесу просування товару від виробників до споживачів за рахунок вдалого поєднання його споживчих та економічних властивостей; - сформувати виважену стратегію і тактику постачання, виробництва та збуту" [10, с. 95].

Формування конкурентоспроможності продукції забезпечується в результаті діяльності відповідного товаровиробника під впливом комплексу взаємопов'язаних між собою чинників, які в межах наукових досліджень і практичного аналізу поділяються за середовищем виникнення (зовнішні, внутрішні), за вартісною характеристикою (цінові, нецінові), за характером дії (основні, додаткові), за тривалістю дії (постійні, змінні), за сферою впливу (маркетингові, економічні, виробничі, науково-технічні, екологічні тощо) [5, с. 69].

На сучасному етапі розвитку вітчизняної економіки вплив цих чинників певною мірою сприяв підвищенню конкурентоспроможності агропродовольчої продукції підприємств АПК України, що знайшло відображення (табл. 1) в зростанні обсягів експорту на зовнішні ринки продукції рослинництва (зростання - на 28,9\% до рівня 2017 р.), значно меншою мірою - продуктів тваринного походження (зростання - на 7,2\%). Проте навіть такі достатньо позитивні зміни не вирішують проблеми існування серед всієї номенклатури сільськогосподарської продукції таких іiі видів, конкурентоспроможність яких є вкрай низькою та малоперспективною (що було наочно відображено ще в статті Н. Дугієнко та О. Симоненко, рис. 1).

Експерти відзначають, що конкурентоспроможність вітчизняної продукції АПК на зовнішніх ринках не підвищується бажаними темпами через вкрай обмежену номенклатуру видів агропродовольчої продукції, орієнтованих на експорт (за 
даними статистики, частка таких видів, як зернові культури, олія та насіння олійних культур, у загальних обсягах експорту регулярно становить не менше як $60 \%)$.

Також достатньо регулярними є випадки виявлення невідповідності експортованої з України агропродовольчої продукції міжнародним стандартам безпеки та якості продуктів харчування. Разом з тим, подальше зростання обсягів імпорту за всіма позиціями, відображеними в табл. 2, на наш погляд, свідчить про фактичну поразку вітчизняних підприємств АПК у конкурентній боротьбі з сільгоспвиробниками із зарубіжжя.

Товарна структура експорту товарів рослинного та тваринного

Таблиияя 1 походження з України у 2017 та 2020 роках

(побудовано авторами за [11])

\begin{tabular}{|c|c|c|c|c|c|c|}
\hline \multirow[b]{2}{*}{$\begin{array}{c}\text { Код і назва товарів згідно } \\
\text { з УКТЗЕД }\end{array}$} & \multicolumn{2}{|c|}{2017 p. } & \multicolumn{4}{|c|}{2020 p. } \\
\hline & $\begin{array}{l}\text { тис. дол. } \\
\text { США }\end{array}$ & $\begin{array}{c}\text { у \% до } \\
\text { загаль- } \\
\text { ного } \\
\text { обсягу }\end{array}$ & $\begin{array}{l}\text { тис. дол. } \\
\text { США }\end{array}$ & $\begin{array}{c}\text { у \% до } \\
\text { загаль- } \\
\text { ного } \\
\text { обсягу }\end{array}$ & $\begin{array}{l}\text { у \% до } \\
2017 \text { p. }\end{array}$ & $\begin{array}{c}\text { зміна частки } \\
\text { в обсязі } \\
\text { експорту, \% }\end{array}$ \\
\hline $\begin{array}{l}\text { I. Живі тварини; продукти } \\
\text { тваринного походження }\end{array}$ & 1108757,0 & 2,6 & 1188164,7 & 2,4 & 107,2 & $-0,2$ \\
\hline 01 живі тварини & 45708,8 & 0,1 & 51506,9 & 0,1 & 112,7 & 0 \\
\hline 02 м’ясо та їстівні субпродукти & 531240,1 & 1,2 & 652106,9 & 1,3 & 122,8 & 0,1 \\
\hline $\begin{array}{l}04 \text { молоко та молочні продукти, } \\
\text { яйця птиці; натуральний мед }\end{array}$ & 494207,3 & 1,1 & 426541,7 & 0,9 & 86,3 & $-0,2$ \\
\hline $\begin{array}{l}\text { II. Продукти рослинного } \\
\text { походження }\end{array}$ & 9215707,9 & 21,3 & 11883238,0 & 24,2 & 128,9 & 2,9 \\
\hline 07 овочі & 235369,3 & 0,5 & 168147,4 & 0,3 & 71,4 & $-0,2$ \\
\hline 08 їстівні плоди та горіхи & 195287,3 & 0,5 & 238390,2 & 0,5 & 122,1 & 0 \\
\hline 10 зернові культури & 6501134,3 & 15,0 & 9410668,9 & 19,1 & 144,8 & 4,1 \\
\hline $\begin{array}{l}11 \text { продукція борошномельно- } \\
\text { круп’яної промисловості }\end{array}$ & 181891,4 & 0,4 & 154490,8 & 0,3 & 84,9 & $-0,1$ \\
\hline $\begin{array}{l}12 \text { насіння і плоди олійних } \\
\text { рослин }\end{array}$ & 2060121,4 & 4,8 & 1842430,9 & 3,7 & 89,4 & $-1,1$ \\
\hline Усього & 43264736,0 & 100,0 & 49191824,5 & 100,0 & 113,7 & 0 \\
\hline
\end{tabular}

\section{Група конкурентоспроможної продукції}

насіння соняшнику, продукти його переробки, насіння ріпаку, сої та продукти їх переробки, продовольче та фуражне зерно

\section{Група перспективної конкурентоспроможності}

м'ясо птиці, овочі, яйця, молоко та молочні продукти, свинина, мед, картопля

\section{Група продукції з низькою перспективою створення конкурентоспроможності}

яловичина, цукор, льон

Рис. 1. Групи сільськогосподарської продукції за рівнем ії конкурентоспроможності (джерело: [10]) 


\section{Herald of Lviv University of Trade and Economics. Economic Sciences. № 64, 2021}

Таблиия 2

\section{Товарна структура імпорту товарів рослинного та тваринного походження в Україну у 2017 та 2020 роках}

(побудовано авторами за [11])

\begin{tabular}{|c|c|c|c|c|c|c|}
\hline \multirow[b]{2}{*}{$\begin{array}{c}\text { Код і назва товарів згідно } \\
\text { з УКТЗЕД }\end{array}$} & \multicolumn{2}{|c|}{$2017 \mathrm{p}}$. & \multicolumn{4}{|c|}{$2020 \mathrm{p}$. } \\
\hline & $\begin{array}{l}\text { тис. дол. } \\
\text { США }\end{array}$ & $\begin{array}{c}\text { у\% до } \\
\text { загаль- } \\
\text { ного } \\
\text { обсягу }\end{array}$ & $\begin{array}{l}\text { тис. дол. } \\
\text { США }\end{array}$ & $\begin{array}{c}\text { у \% до } \\
\text { загаль- } \\
\text { ного } \\
\text { обсягу }\end{array}$ & $\begin{array}{l}\text { у \% до } \\
2017 \mathrm{p} .\end{array}$ & $\begin{array}{c}\text { зміна } \\
\text { частки в } \\
\text { обсязі } \\
\text { імпорту, \% }\end{array}$ \\
\hline $\begin{array}{l}\text { I. Живі тварини; продукти } \\
\text { тваринного походження }\end{array}$ & 731549,5 & 1,5 & 1258069,2 & 2,3 & 172,0 & 0,8 \\
\hline 01 живі тварини & 57432,5 & 0,1 & 80912,1 & 0,1 & 140,9 & 0 \\
\hline 02 м'ясо та їстівні субпродукти & 112024,7 & 0,2 & 165030,6 & 0,3 & 147,3 & 0,1 \\
\hline $\begin{array}{l}04 \text { молоко та молочні продукти, яйця } \\
\text { птиці; натуральний мед }\end{array}$ & 84884,5 & 0,2 & 308396,9 & 0,6 & 363,3 & 0,4 \\
\hline II. Продукти рослинного походження & 1368027,1 & 2,8 & 1989254,2 & 3,7 & 145,4 & 0,9 \\
\hline 07 овочі & $\overline{75995,2}$ & 0,2 & 262576,7 & 0,5 & 345,5 & 0,3 \\
\hline 08 їтівні плоди та горіхи & 477254,8 & 1,0 & 795560,2 & 1,5 & 166,7 & 0,5 \\
\hline 10 зернові культури & 176756,1 & 0,4 & 178913,7 & 0,3 & 101,2 & $-0,1$ \\
\hline $\begin{array}{l}11 \text { продукція борошномельно- } \\
\text { круп’яної промисловості }\end{array}$ & 32240,2 & 0,1 & 35170,5 & 0,1 & 109,1 & 0 \\
\hline 12 насіння і плоди олійних рослин & 358269,9 & 0,7 & 388154,1 & 0,7 & 108,3 & 0 \\
\hline Усього & 49607173,9 & 100,0 & 54336136,7 & 100,0 & 109,5 & 0 \\
\hline
\end{tabular}

Особливо виразно проблеми недостатньої конкурентоспроможності вітчизняної агропродовольчої продукції відображаються на полицях мережевих торговельних компаній України, які в 20192021 рр. здійснювали закупівлю та подальшу реалізацію імпортних полуниць, черешень, винограду, груш, яблук, томатів, баштанних та інших культур, які можуть вирощуватися вітчизняними сільгоспвиробниками (у даному випадку не йдеться про субтропічні чи тропічні культури) [12].

Подібні питання виникають і щодо продукції українських товаровиробників на внутрішньому ринку продовольства, на якому майже непоміченими пройшли зумовлені світовою пандемією COVID-19 процеси скорочення обсягів виробництва та споживання в сусідніх із нами країнах Європи, де на прилавках дефіциту імпортної агропродовольчої продукції не спостерігалося. Натомість в Україні вітчизняні фермери, за свідченнями 3MI, в 2021 р. вимушені були продавати оптом баштанну продукцію за цінами, що не покривали навіть собівартості іiі вирощування, а експортувати, для прикладу, кавуни в країни СС не було можливості через невідповідність їх вимогам європейських споживачів (які віддають перевагу гібридним безнасіннєвим сортам із невеликими об'ємними та масовими габаритами) та через занадто дорогу логістику, зумовлену зростанням вартості транспортування. Але ж все це $є$ реальним проявом недостатньої конкурентоспроможності вітчизняної агропродовольчої продукції, що стало наслідком неналежного рівня роботи вітчизняних товаровиробників із прогнозування майбутніх економічних умов та невміння правильно виміряти, оцінити потенціальну динаміку конкурентоспроможності продукції.
Загальновизнано, що конкурентоспроможність продукції $\epsilon$ за своїм характером показником відносної оцінки, а тому кількісне вимірювання вищевказаних аспектів повинно забезпечуватися переважно на основі експертних порівняльних оцінок аналізованої продукції певного товаровиробника 3 наявними на ринку товарами аналогічного функціонального призначення, які займають лідерські позиції на даному ринку. Для цього економічною наукою сформовано систему параметрів конкурентоспроможності продукції, за якими мають проводитися відповідні порівняння i яка 3 врахуванням специфіки галузевих особливостей оцінки конкурентоспроможності включає такі основні групи параметрів, як технічні (технічні та фізичні властивості товару, його функції в процесі використання/споживання), економічні (рівень витрат на виробництво, ціни споживання, витрати на купівлю, обслуговування, споживання товару, його утилізацію), нормативні (відповідність товару встановленим нормам, стандартам, іншим вимогам). Для проведення такого оцінювання можуть бути застосовані різні апробовані на практиці методи, які в систематизованому вигляді відображені на рис. 2 та які базуються на оцінюванні різних груп параметрів конкурентоспроможності продукції.

Підсумком проведення процедур оцінювання конкурентоспроможності продукції (за алгоритмом, наведеним на рис. 3) має стати визначення рівня відповідності умов пропозиції продукції та потреби в ній з боку споживачів певної цільової групи; при цьому ключовою умовою забезпечення успішності такої взаємодії потреби і товару (продукції) залишається якість виробу [9, с. 292]. 


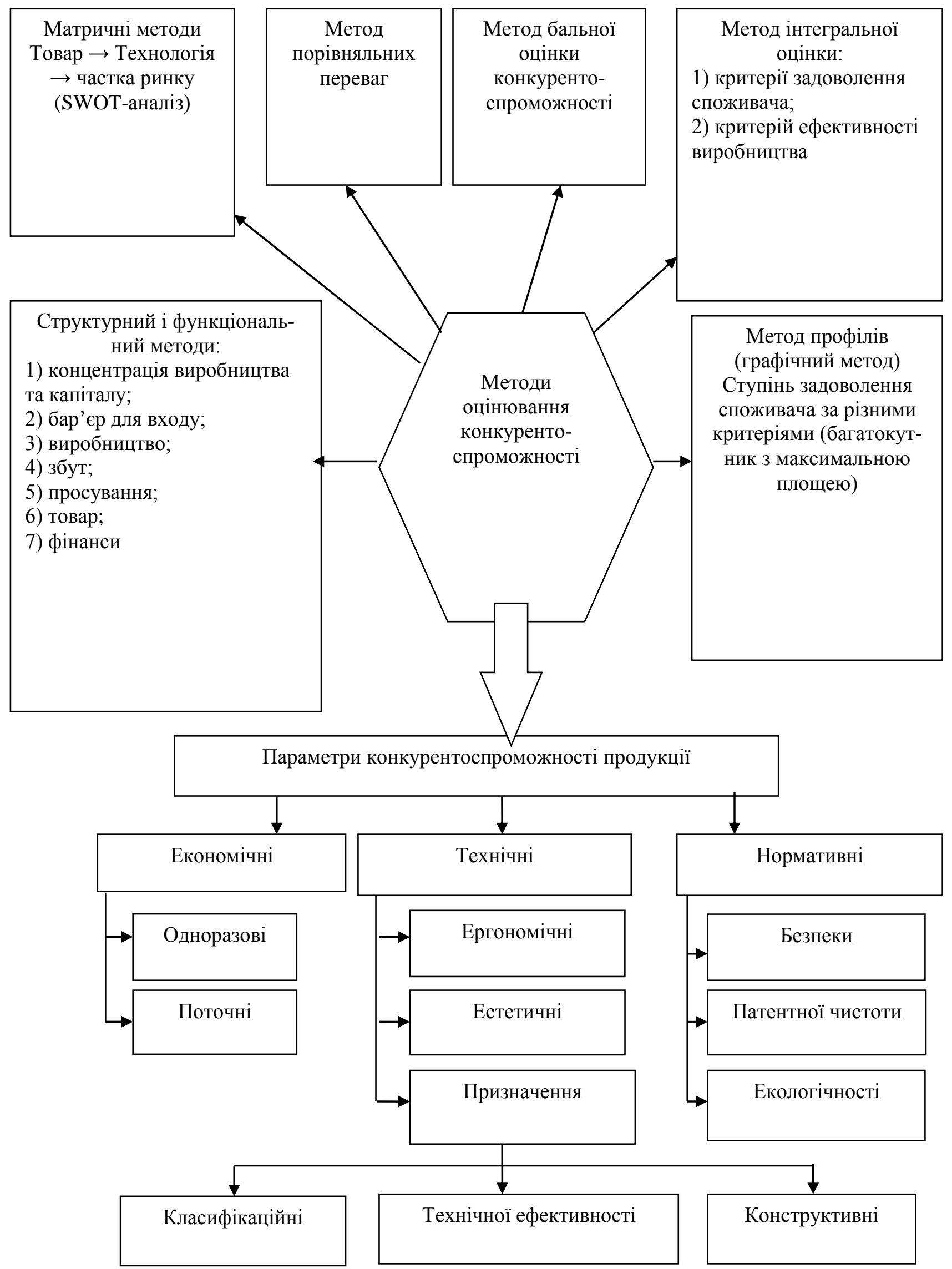

Рис. 2. Методи та об'єкти оцінювання конкурентоспроможності продукції (розроблено авторами на основі: [9, с. 290], [7, с. 36]) 


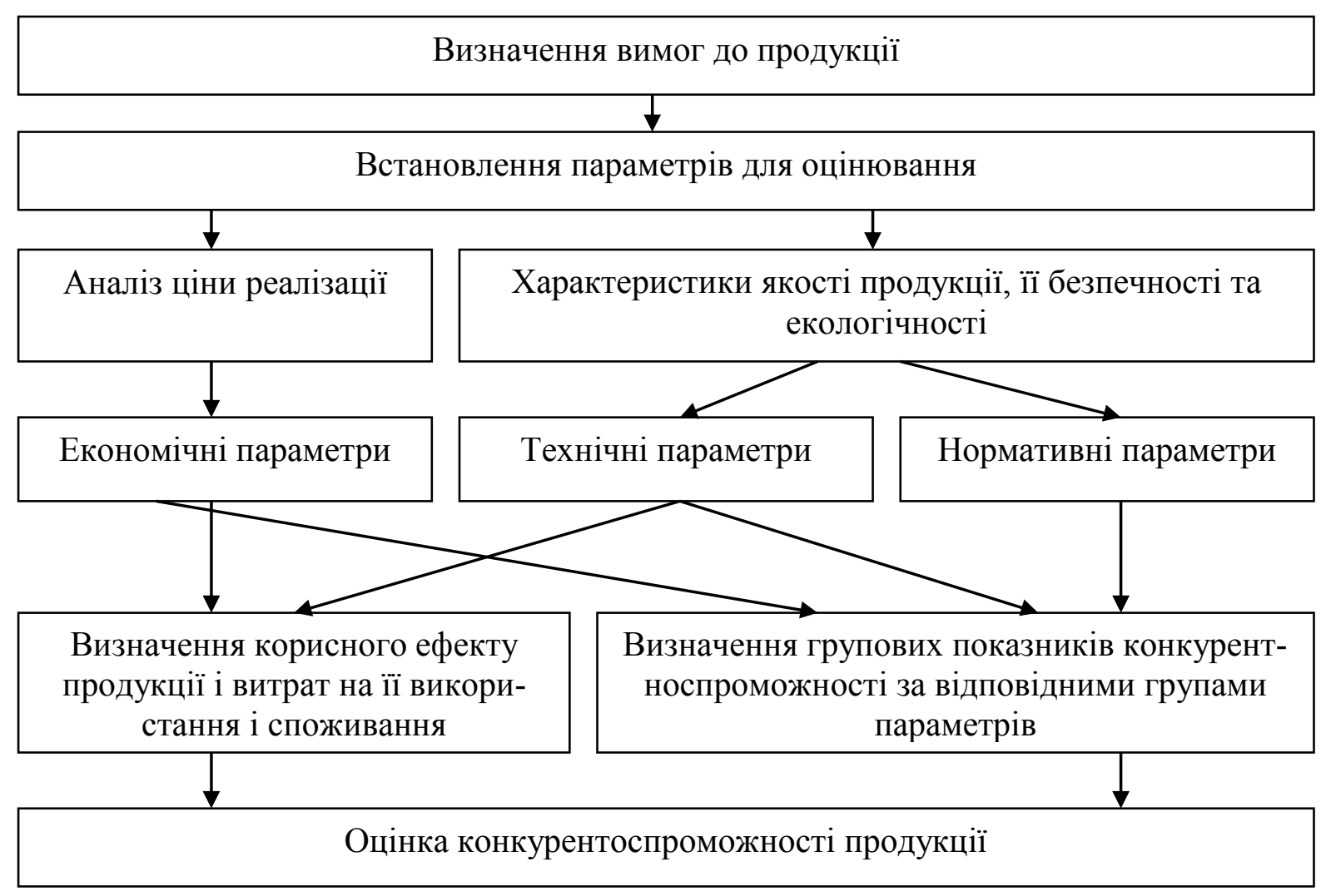

Рис. 3. Алгоритм оцінки рівня конкурентоспроможності продукції (удосконалено на основі: [14])

Зважаючи на це, перед АПК України постає завдання щодо зміцнення конкурентоспроможності продукції агропідприємств завдяки активним впливам на зовнішні (державне регулювання економіки, інтеграційні процеси, модернізація вітчизняного АПК, відновлення практики державних і регіональних закупівель сільгосппродукції в економічно виправданих масштабах, прискорення процесу впровадження міжнародних стандартів безпеки та якості продуктів харчування (HACCP, ISO, EN, Кодексу Аліментаріус) у сфері агропромислового виробництва, розвиток органічного землеробства, удосконалення механізмів регулювання агропродовольчих ринків, розвиток інформаційних технологій, удосконалення стану і структури ринку, розгортання його інфраструктури, нарощування ємності ринку через активну соціальну політику, органічне зростання вимог споживачів) та внутрішні (організаційно-виробнича діяльність підприємства, кваліфікація персоналу, ефективність використання ресурсного потенціалу, система управління конкурентоспроможністю) чинники, які охоплюють сферу виробництва і збуту продукції, стан ринкового середовища тощо. В даному контексті доцільними будуть зусилля вітчизняних товаровиробників із організаційного та технологічного оновлення аграрного виробництва, розбудови експортної інфраструктури, а також із забезпечення відповідності технологічних процесів вимогам міжнародних угод щодо ветеринарних i фітосанітарних вимог до аграрної продукції тощо.
Особливу увагу варто звернути на необхідність вирішення проблеми роздробленості аграрного сектора України, в якому майже половину продукції виробляють особисті селянські господарства та дрібні товаровиробники (39,5 \% продукції рослинництва та 54,2 \% продукції тваринництва у 2017 р.) [15, с. 137], а тому потрібно забезпечити швидку інтеграцію особистих господарств населення у ринкові механізми функціонування аграрного сектора, сприяти розвитку виробничих і збутових сільськогосподарських кооперативів, зорієнтованих на спільне ведення господарської діяльності дрібними товаровиробниками, що забезпечить зменшення витрат на виробництво і збут їх агропродовольчої продукції.

Висновки i перспективи подальших досліджень у даному напрямі. Інтеграція української економіки в європейську та світову економіку спонукає та примушує вітчизняних виробників аграрного сектора виготовляти продукцію високоефективну і конкурентоспроможну. Вирішення основних проблем досягнення ефективної діяльності підприємств АПК України на внутрішньому i зовнішньому ринках має забезпечуватися шляхом підвищення конкурентоспромож-ності агропродовольчої продукції з досягненням нею вищого в порівнянні 3 наявними на ринку товарамианалогами рівня за технічними, економічними та нормативними параметрами та за умови збереження ключової ролі якісних характеристик готової продукції. 3 цією метою підприємствам АПК необхідно використовувати в господарській діяльності 
практику оцінювання фактичної конкурентоспроможності власної аграрної продукції та прогнозного іiі розвитку за умови реалізації комплексу заходів із забезпечення іiі зростання. Подальші дослідження мають спрямовуватися на розробку на перспективу системи заходів із цільового забезпечення підвищення конкурентоспроможності агропродовольчої продукції підприємств АПК України.

\section{ЛIТЕРАТУРА}

1. Захарчук О. В. Світовий ринок овочів та місце України / Захарчук О. В. // Агросвіт. - 2018. № 3. - С. 3-7.

2. Кругляк О. В. Інноваційні фактори та конкурентоспроможність галузі молочного скотарства / Кругляк О. В. // Економіка АПК. - 2018. № 6. - С. 76-86.

3. Мазнєв Г. Є. Інноваційна діяльність як фактор підвищення ефективності агровиробництва / Мазнєв Г. С. // Актуальні проблеми інноваційної економіки. - 2016. - №2. - С. 36-47.

4. Пугачов М. І. Розвиток зовнішньої торгівлі агропродовольчими товарами / Пугачов М. I. // Економіка АПК. - 2019. - №3. - С. 6-13.

5. Желуденко К. В. Сутність та фактори конкурентоспроможності продукції підприємств України / К. В. Желуденко // Інтелект ХХІ. - 2017. - № 1. C. 66-71.

6. Конкурентоспроможність продукції скотарства і птахівництва України в системі євроінтеграції : монографія / [M. М. Ільчук, I. А. Коновал, І. В. Мельникова та ін.]. - К. : Вид-во ТОВ “Аграр Медіа Груп”, 2015. - 321 с.

7. Драган О. І. Управління конкурентоспроможністю підприємств: теоретичні аспекти : монографія / О. І. Драган. - К. : ДАКККіМ, 2006. - 160 с.

8. Гринь В. І. Сутність та фактори конкурентоспроможності продукції сільськогосподарських підприємств / В. І. Гринь // Наукові праці Полтавської державної аграрної академії. - 2012. - Вип. 2 (5). Т. 3. - C. 87-92.

9. Бурачек I. В. Конкурентоспроможність продукції підприємств: сутність, методи оцінки та зарубіжний досвід управління / I. В. Бурачек, О. О. Біленчук // Глобальні та національні проблеми економіки : електронне наукове фахове видання; Миколаївський національний університет імені В. О. Сухомлинського. - 2016. - Вип. 14. C. 288-293.

10. Серединська В. М. Конкурентоспроможність продукції: значення та сфера застосування / Серединська В. М., Загородна О. М. // Інфраструктура ринку. - 2017 . - № 4 . C. 93-98.

11. Дугієнко Н. О. Конкурентоспроможність АПК України в умовах євроінтеграції / Н. О. Дугієнко, О. О. Симоненко // Глобальні та національні проблеми економіки : електронне наукове фахове видання; Миколаївський національний університет імені В. О. Сухомлинського. - 2015. Вип. 5. - С. 81-84.
12. Стало відомо, імпорт яких фруктів в Україну зростає найшвидше [Електронний ресурс]. - Режим доступу : https://agronews.ua/news/stvlovidomo-import-iakykh-fruktiv-v-ukrainu-zrostaienayshvydshe/.

13. Товарна структура зовнішньої торгівлі України [Електронний ресурс]. - Режим доступу: http://www.ukrstat.gov.ua/operativ/operativ2021/zd/tsz tt/tsztt_u/arh_tsztt2021_u.html.

14. Попадинець Н. М. Конкурентоспроможність продукції аграрного сектору на внутрішньому та зовнішньому ринках / Н. М. Попадинець // Молодий вчений. - 2015. - № 2(6). С. 1330-1333 [Електронний ресурс]. - Режим доступу: http: //nbuv.gov.ua/UJRN /molv_2015_2\% 286\% $29 \_330$

15. Патика Н. Пріоритети забезпечення конкурентоспроможності сільського господарства України на світових ринках / Патика Н. // Agricultural and Resource Economics: International Scientific E-Journal. - 2018. - Vol. 4. No. 4. - Pp. 130145 [Електронний ресурс]. - Режим доступу: http://are-journal.com.

\section{REFERENCES}

1. Zakharchuk, O. V. (2018), Svitovyj rynok ovochiv ta mistse Ukrainy, Ahrosvit, № 3, s. 3-7.

2. Kruhliak, O. V. (2018), Innovatsijni faktory ta konkurentospromozhnist' haluzi molochnoho skotarstva, Ekonomika APK, № 6, s. 76-86.

3. Mazniev, H. Ye. (2016), Innovatsijna diial'nist' iak faktor pidvyschennia efektyvnosti ahrovyrobnytstva, Aktual'ni problemy innovatsijnoi ekonomiky, №2, s. 36-47.

4. Puhachov, M. I. (2019), Rozvytok zovnishn'oi torhivli ahroprodovol'chymy tovaramy, Ekonomika APK, №3, s. 6-13.

5. Zheludenko, K. V. (2017), Sutnist' ta faktory konkurentospromozhnosti produktsii pidpryiemstv Ukrainy, Intelekt KhKhI, № 1, s. 66-71.

6. Konkurentospromozhnist' produktsii skotarstva i ptakhivnytstva Ukrainy $\mathrm{v}$ systemi ievrointehratsii : monohrafiia, M. M. Il'chuk, I. A. Konoval, I. V. Mel'nykova ta in. (2015), Vyd-vo TOV “Ahrar Media Hrup", K., 321 s.

7. Drahan, O. I. (2006), Upravlinnia konkurentospromozhnistiu pidpryiemstv: teoretychni aspekty : monohrafiia, DAKKKiM, K., $160 \mathrm{~s}$.

8. Hryn', V. I. (2012), Sutnist' ta faktory konkurentospromozhnosti produktsii sil's'kohospodars'kykh pidpryiemstv, Naukovi pratsi Poltavs'koi derzhavnoi ahrarnoi akademii, Vyp. 2 (5). T. 3., s. 87-92.

9. Burachek, I. V. and Bilenchuk, O. O. (2016), Konkurentospromozhnist' produktsii pidpryiemstv: sutnist', metody otsinky ta zarubizhnyj dosvid upravlinnia, Hlobal'ni ta natsional'ni problemy ekonomiky : elektronne naukove fakhove vydannia; Mykolaivs'kyj natsional'nyj universytet imeni V. O. Sukhomlyns'koho, vyp. 14, s. 288-293.

10. Seredyns'ka, V. M. and Zahorodna, O. M. (2017), Konkurentospromozhnist' produktsii: 
znachennia ta sfera zastosuvannia, Infrastruktura rynku, № 4, s. 93-98.

11. Duhiienko, N. O. and Symonenko, O. O. (2015), Konkurentospromozhnist' APK Ukrainy v umovakh ievrointehratsii, Hlobal'ni ta natsional'ni problemy ekonomiky : elektronne naukove fakhove vydannia; Mykolaivs'kyj natsional'nyj universytet imeni V. O. Sukhomlyns'koho, vyp. 5, s. 81-84.

12. Stalo vidomo, import iakykh fruktiv v Ukrainu zrostaie najshvydshe, available at: https://agronews.ua/news/stvlo-vidomo-import-iakykhfruktiv-v-ukrainu-zrostaie-nayshvydshe/.

13. Tovarna struktura zovnishn'oi torhivli Ukrainy, available at: http://www.ukrstat.gov.ua/operativ/ operativ2021/zd/tsztt/tsztt_u/arh_tsztt 2021_u.html.
14. Popadynets', N. M. (2015), Konkurentospromozhnist' produktsii ahrarnoho sektoru na vnutrishn'omu ta zovnishn'omu rynkakh, Molodyj vchenyj, № 2(6), s. 1330-1333, available at: http: //nbuv.gov.ua/UJRN/molv_2015_2\% 286\% 29_330

15. Patyka N. (2018), Priorytety zabezpechennia konkurentospromozhnosti sil's'koho hospodarstva Ukrainy na svitovykh rynkakh, Agricultural and Resource Economics: International Scientific E-Journal, Vol. 4. No. 4., pp. 130-145, available at: http://arejournal.com.

Стаття надійшла до редакиії 03 серпня 2021 року 